\title{
Status of Women in Uzbekistan through the Prism of Family Relationship and Education
}

\author{
Natalya BazarovnaRajapova ${ }^{1}$, ManzuraNasrullaevnaNazarova ${ }^{2}$ \\ ${ }^{1}$ Lecturer,Termez State University, nradjapova@inbox.ru \\ ${ }^{2}$ Lecturer,Termez State University
}

\begin{abstract}
The article examines the historically established concepts of the differences and similarities in men and women. Gender stereotypes that hinder the economic, cultural, social development of girls and women. Examples of reforms carried out in the society to establish gender equality are given. The goals of involving women in social activities and the economic life of the country, the formation and change of official concepts of state regulation of the family are investigated.Fundamentals of the gender order formed by state policy to achieve gender equality at the present time.
\end{abstract}

Keywords:gender, gender equality, constitution, code, economics, history, family, citizen, law, state, personality, entrepreneurship.

Article Received: 10 August 2020, Revised: 25 October 2020, Accepted: 18 November 2020

\section{INTRODUCTION}

Society has a hard time overcoming historical gender stereotypes and always has a hard time accepting female leadership. The formation of democratic institutions and the development of political culture, in turn, contribute to the development of equality in society with respect to political law. Stereotypes about abilities and role functions make themselves felt in the event of various crises. As a rule, women become candidates for dismissal, and when hiring a job, they give preference to a man. Due to this, the unemployment rate among women is higher than among men. In society, it develops, so that women receive less pay for the same work, plus the process of ousting women from positions of high pay and having prospects is noticeable. In gender relations, communication is also formed in the private sphere, the basis of which is the family, which dominates among other social institutions. Basically, interpersonal relationships arising in a person's family environment are formulated here. In the construction of gender, it is precisely the concepts of home and family that are the source of a certain experience of a woman and, at the same time, her focus of suppression and
oppression.Gender roles are assigned on the basis of traditional gender socialization with patriarchal attitudes at home and family. It is in the construction of unequal opportunities for women and men that the rules and rights of the "home world", the place of a man in it plays an important role. The perception and assessment of family information is manifested in everyday life and defines gender as an important category of social life. For example, in the modern family of Uzbekistan, the word "woman" is associated with the concepts of home, household, motherhood, children, upbringing, etc. And the word "man" is close to the concepts of family support, financial income, the role of father and protector, etc. L.V. Shtylevaya defines gender stereotypes as "stable for a given society in a given historical period, ideas about the differences between men and women" [1, p. 17].

\section{THE MAIN FINDINGS AND RESULTS}

Gender stereotypes of a family character describe the qualities and characteristics of a man and a woman; contain normative patterns of behavior taking into account gender, reflecting generalized opinions and ideas about a man and a woman. 
Certain social roles are assigned to both women and men. For example, in society, a man is assessed by his professional success, and a woman is assessed by having a family and children.

The family, in the process of presenting a model of behavior, sets an example of the assimilation of sexual significance. The social institution of the family helps to assimilate the stereotypes of a given society from childhood. Thanks to the transmission from generation to generation, they persist for hundreds of years.

Parents-to-be always want to know the gender of the child in advance. Depending on this, they begin to choose a name, clothes, and toys for the newborn. The study showed that depending on gender, girls are chosen toys aimed at interacting with other people, such as dolls, dishes, soft toys; boys buy toys that develop motor and cognitive activity, such as cars, construction sets, robots. Fathers with sons are active, and with girls they are more emotional. Parents make certain specific approaches in raising children; this is especially evident when preparing for family life. Traditional families show a desire to have sons as successors of the clan and see in him material support in the future. It is this desire that leads to the infringement of the rights of girls. The result is activity, perseverance, and self-confidence, intelligence in boys and compliance, passivity, dependence in girls. The family becomes the pledge of responsibility, purposefulness, masculinity in future men and good breeding, modesty, femininity in future women.

On the one hand, gender stereotypes help to assimilate the information of society, with the help of them it is easy for a person to be identified in society. On the other hand, gender stereotypes generate false generalizations about all categories of people. In the further development of the individual, gender stereotypes begin to act negatively. For example, the preference for the male gender dominates the female sex in the process of education in school and other educational institutions. As a consequence, obstacles of this type hinder the development of the internal potential that each person is endowed with by nature. Belonging to the biological sex inhibits internal motivation, which contributes to the activation and development of positive qualities. Further, gender inequality begins to manifest itself in the economic sphere, employment, employment and the distribution of other opportunities.

The theory of construction and predetermination of gender by society suggests that since it exists, the construction of gender means its rebuilding is also natural. Rebuilding gender does not mean eliminating the differences between men and women. The restructuring should result in a society of equal people, where hierarchical, status stereotypes will not rule, and the domination of equal opportunities will be ensured.

The spread of the ideas of democracy and the revitalization of the women's movement in society have an impact on the weakening of prejudices about gender. However, despite democratic changes, gender stereotypes continue to influence society. Basically, they are reproduced under the pressure of tradition, customs, education system, upbringing and other components of a person's spiritual life. Formation of tolerance, diversity, equality and innovation in modern society can weaken traditional gender stereotypes, but not destroy them. Because all components of spiritual life are an integral part of a person's entire life.

Gender stereotypes predetermine future professional activities and subsequent employment of women. The choice of the direction of education is made taking into account the maximum benefits for the family. Girls choose the profession that will be beneficial in the future to her family, and not the one in which she can climb the career ladder. The result is such specialties as a medical worker, teacher, and dressmaker. Due to the lack of educational training, vocational qualifications and skills, women in rural areas are significantly less busy in employment. In rural areas, informal low-paid seasonal work, which often leaves women without social 
protection, contributes to the family budget. Basically, women can rely on income from subsidiary farming or handicrafts.

The morals of marriage and family are the foundations of modern society. After receiving compulsory secondary vocational education, parents prefer to marry the girl off rather than continue her education. If a girl has benefits or enters, she will have a chance to continue her studies and get higher education at a university on state payment. But if a girl enters to study for a paid education, the family does not always meet halfway. Since, according to custom, when a girl gets married, she leaves her father's house, the parents usually do not invest in her education. It will be more profitable to teach the son, who in the future will bring benefits to the family budget. Young men, continuing their education in a higher educational institution or finding a decent job, may get married at a more mature age, which is not typical for girls. In the course of this development of affairs, an asymmetry arises in the higher education system of Uzbekistan. Gender stereotypes have a significant impact on the choice of profession for women and men. The accumulation of women in education and health care is explained by the fact that it is more convenient for a family to have a daughter-in-law, a teacher or a nurse. Factors such as shorter working hours, lack of overtime hours, and a predominantly female environment also influence future career choices.

The Constitution of the Republic of Uzbekistan guarantees free secondary education for every citizen. The educational system of Uzbekistan begins with a preschool structure, followed by compulsory primary education, general secondary or secondary specialized at the discretion of citizens. Higher education is the implementation of academic and professional programs based on state standards. In all spheres and processes of education, women are mainly involved as educators, nannies, psychologists, teachers, teachers, mentors, tutors, etc.

In recent years, the state has begun to implement reforms for the development of spheres at all educational distances. For example, in 2017, the Ministry of Preschool Education was created [2]. The development of this area creates conditions for high-quality education of the younger generation. The sector for the creation of public and private preschool institutions provides an opportunity for women to realize themselves in professional activities. If earlier parents left small children at home under the supervision of older family members, more often older children, and often older girls, this situation gave rise to a number of gender-type problems.Girls lost the opportunity to develop their potential, school performance declined, educational success was lost, and the stereotype of the family and its responsibilities were instilled. The emergence of new kindergartens ensures the correct organization of the time of women and girls in general. The Children's Commission under the Ministry of Justice and the Ministry of Public Education oversee the schooling of children. In primary and general secondary education, gender parity is practically ensured.

The legislation of Uzbekistan does not have gender restrictions in obtaining higher education. However, this education sector remains imbalanced. In higher educational institutions there are about $40 \%$ of girls, while there are more than $60 \%$ of boys. Such a low percentage of female participation and its further decline will lead to a serious problem in the labor market.

The preference for boys in higher education and the reluctance of parents in favor of the preserved principles of sending their daughters far from home to study, financial shortage are becoming the main reasons for asymmetries in higher education.

In the presidential decree "On the Strategy of Actions for the Further Development of the Republic of Uzbekistan" dated February 7, 2017, reforms in the spheres of education were outlined. In the course of the work done, the result was new educational institutions of higher profile. For example, branches of the capital's universities have opened in the regions, institutes have 
appeared, studying in which creates an opportunity not to leave their native places. The only Termez State University existed in the remote region of Surkhandarya before the adoption of the "Strategy of Actions". After educational reforms in the region, three branches of higher educational institutions were created at once: the Termez branches of the Tashkent Medical Academy and the Tashkent State Pedagogical University named after Nizami, the Denau branch of the Termez State University. Further, the Termez branch of the Tashkent State Technical University named after Islam Karimov was formed, and the Denau branch of the Termez State University was transformed into an independent university with an institute of entrepreneurship and pedagogy and the Termez branch of the Tashkent State Agrarian University.

Large-scale reforms carried out by the state in education, aimed at improving the quality of education and improving the system, have led to changes in gender position. For example, in 2017, over 15 higher educational institutions opened correspondence forms of directions in various specialties. The purpose of this event is to attract students who combine education with work, sports or other activities. Part-time education also has a lower commercial cost. In turn, this helped young women who received the opportunity to get higher education without interrupting their family, children and their family responsibilities. In addition, reforms were carried out regarding contract payment. Lower tuition fees in tertiary education also contribute to a significant increase in female students; as the population's awareness of the value of higher education grows, the attitude of families towards this area changes. The family wants to take a daughter-in-law with a higher education, because this way she will have a high potential for contributing to the family budget.

The percentage of girls and boys in the total number of students in the systems of general secondary and secondary special education has a difference of slightly $2 \%$, which cannot be said about the personnel structure of the education system in general. In the personnel space of the education system, women dominate, creating an imbalance of over $70 \%$. The specificity of gender distribution is observed partly in certain categories of employees. More than $70 \%$ of women as part of the teaching staff confirm the stereotype that a woman should be a teacher. The hierarchy of leadership, the higher, the more reflects the vertical segregation of women. If in preschool educational institutions women are managers - 97\%, in primary schools - women - directors - $65 \%$, then in colleges and lyceums men are beginning to dominate $-87 \%$, and there are only two women rectors.

The causes of vertical segregation are becoming gender issues. The formation of these problems occurs in the systems of social institutions of education and learning processes. Generative phenomena, gender inequality are in the admission to study, in the learning processes themselves and in the further distribution of personnel performances.

Today, in the Republic of Uzbekistan, gender equality takes a $10 \%$ advantage in favor of men at all levels of education. There is a disproportionate ratio of men and women studying in various types of institutions. Economic problems are not always the only reason for the gap between the share of male and female students in higher education. Educational reforms are promoting access to higher education. Basically, women predominate in secondary specialized educational institutions. In institutions of primary vocational education, the percentage of participation of women is slightly decreasing. Higher education admissions have a significant imbalance in numbers. In addition, the imbalance manifests itself in industry specialization. If in special educational institutions there are more women by $4-5 \%$, then in industry specializations this percentage reaches from $10 \%$ to $50 \%$. For example, men are significantly ahead of women in numbers in faculties and specialties related to industry, agriculture, transport, economics, law, communications, physical education and sports [3, pp. 61, 63]. The 
number of women predominates mainly in the fields of education and health care; hence, the difference in the number in the choice of profession.

Recently, the number of women in postgraduate education has increased. Taking advantage of all the benefits of society, knowing her rights and responsibilities, a woman seeks to prove herself in society, contributing to scientific and technological progress. Therefore, the number of women who have shown a desire to engage in scientific activities is rapidly growing. But even here a number of questions arise that await their optimal solution.

The first is the connection between the choice of specialization and the concept of the biological sex of scientific researchers. Depending on the specialization of the gender, women prefer research in the field of art history, psychology, sociology, philology, pedagogy, and pharmacology. And men conduct their research in areas such as agricultural, veterinary, legal, physical and mathematical, technical, geology, mineralogy and political science. Thus, the expansion of the female scientific circle is not due to the assimilation of new scientific fields by women, but due to an increase in the growth of the number of women in definitely traditional "female" scientific areas.

The second question arises in achieving an advanced degree. Despite the fact that the continent of higher education teachers is mostly made up of half women, the number of women with advanced degrees is not comparable to that of men. If men with a scientific degree of Doctor of Science make up $80 \%$, then $20 \%$, respectively, are women of Doctor of Science. PhDs also have a 30\% margin with a male margin. This figure has persisted for several decades, without observing an increase in the number of women with advanced degrees. Women scientists conduct certain studies, make discoveries, publish articles on the results of these studies, and have achievements and successes. The reasons for the low percentage of women with advanced degrees require further analysis.
This analysis will help to identify the principles of social policy of the state in the field of education and the reasons for ensuring equality regardless of gender for all citizens. Education as one of the areas of social policy fulfills the function of ensuring gender equality, representing the interests of both women and men. Gender equality in education means not only equal opportunities to use the resources of education, but also equal results in the further use of the opportunities provided.

Awareness of the existence of inequalities in education will help to eliminate the obvious causes and all the ensuing consequences.

Is the preference of female students, and then undergraduates and doctoral students, in the fields of health care and education always voluntary? To what extent does the social environment contribute to the choice of the profession of a doctor or a teacher? Disclosure of these issues helps to study the prevailing stereotypes of thinking, the influence of traditions and customs, economic factors.

Community education and general education are mainly associated with the ideas of democracy. Another function of education is not only the acquisition of knowledge, but also the development of the personal potential of each citizen. Equal access to knowledge helps to acquire the necessary professional experience and skills, the availability of which balances wealth and social status. Therefore, education is considered a means of ensuring equality regardless of origin, material self-sufficiency, nationality, religion, and even more so gender. But the ability to achieve through education is still a question for researchers in this field. Often unintentionally educational methods support or reflect gender inequality. For example, the social status of parents influences the educational process of children. Consequently, if both parents have a higher education, a high social status in society, then the children achieve more success in educational activities. Theories that explain the relationship between education and 
inequality in society prove this. For example, Bernstein argued that society through education instills various forms of verbal communication, which ultimately affects the perception of educational processes [4].

In particular, a woman herself sometimes establishes gender inequality in the course of education processes. In the family and schools, a woman plays the main role in the upbringing of children and, following gender stereotypes prevailing in society, she, as it were, predetermines the social roles that children ultimately take. If a woman in a family has a high-quality higher education, is free from gender stereotypes in society, she will be able to raise her children regardless of differences in biological sex. The result of such education should be individuals who do not have gender differences and predetermine the further development of gender equality in society.

The reason for inequality in education lies in the implementation of educational processes that reflect the norms, values, patterns and patterns of behavior of society. If the means of educational organizational activities contain elements that indicate social or gender inequality, then trainers begin to learn rules of conduct that contain gender differences. For example, in textbooks, illustrations of the profession always show that a teacher or a nurse is a woman, a driver; a hairdresser is always a man. Educators capture and remember hidden elements of inequality to develop these skills in the future. Thus, education, showing the cultural and social interests of society, contributes to the development of gender inequality. In part, education reinforces and reproduces traditional gender roles and stereotypes in society.

Democracy is the perfect condition for the development of the foundations of civil society. A condition where people's participation expands in the political, economic, cultural and social spheres of life. Depending on this, the course of state policy determines the development goals. Equal opportunities for all people to access education, health care, employment and political participation contribute to the achievement of the development goal. The Universal Declaration of Human Rights (1948) defines human dignity as "the foundation of freedom, justice and universal peace" [5].

Inequality of fundamental human rights and freedoms leads to the degradation of society, which results in social and political unrest, the spread of violence and the emergence of various conflicts. Despite the fact that gender policy is carried out at the state level, the state provides women with various privileges and guarantees for the protection of their rights, nevertheless, women in society have much less opportunities than those who are dominated by men. This leads to social inequality of the title, which is social stratification. And without taking into account that the proportion of women to potential opportunities is small, their contribution to economic, cultural and social development is much greater than the privileges provided. The low status of women in society and nonobservance of their rights are becoming a serious problem on the way of practical legislation in the field of gender equality.

For example, women, who make up almost half of the population of Uzbekistan, are less likely than men to take positions as administrative workers, managers, and parliament members. Mostly female labor is manifested in those industries where the level of pay is lower. The stereotype of managing finances in the family budget also remains with men. With a small salary, a woman cannot even freely dispose of her finances. Because in the decision of the distribution of family incomes, the majority of the vote remains with men. That is why the development and implementation of pressing issues of gender equality requires long-term, purposeful actions. Only by forming a completely new thinking in cultural, social, political, economic relations, in which stereotypical ideas about women and men will not have a negative impact on action and choice, will civil society be able to develop human potential. 
The factors that contradict the development include family and household, religious traditions, differences in cultural traditions, the influence of the Soviet era. For example, there are family and household traditions that are difficult to correlate with the ideas of gender equality. The payment of kalin (amount of money paid by the groom's expenses) that still exists today, the belittling of the daughter-in-law's status in the husband's family, the prohibition on her communication with relatives, marriage by agreement between the parents, and the early age of marriage hinder human development and the establishment of equality among women and men.

The unequal distribution of family responsibilities, responsibility for children, and caring for parents force a woman to abandon the development of a professional career or force her to adapt, which in turn forms a number of professionally specific "female" sectors of the national economy. For example, service, teaching, healthcare, textiles, etc.

Stereotypes of this type of social thinking isolate a woman from the social life of society. The result of social pressure is the inhibition of self-awareness, powerlessness to defend one's rights in the family and society, low legal literacy, low self-esteem, discrimination as a person. In addition, society imposes specific restrictions on a woman that prevent her from developing freely and comprehensively. A working woman, bearing the burden of household chores and responsibility for the upbringing and education of children, practically loses her free time. The question arises: When should she improve her education, develop intellectually and physically as a person, expand her worldview and social circle of communication? Sometimes a woman is simply absorbed in household chores and raising children.

Therefore, a woman often resigns from the position of manager or director, which allows her to have control over resources. A certain obstacle in the professional growth of a woman is also the presupposing stereotype that a man has more vivid inclinations for leadership, management and leadership. In the course of such a process, a woman again acquires a low status at work and with it less economic power and opportunities, which leads to restrictions in self-education.

Gender equality of the sexes is not limited to a focus on women's issues. The limitations of the possibilities of men are also considered. All gender equality programs and projects study both female and male social roles. In the course of the study, social stereotypes of a "masculine" character are identified, which negatively affect the development of both women and men. There are local and ethnic restrictions on the traditional male role. For example, a man's social status is determined by the amount of his income and success at work. Not always, a certain income and success are of a positive nature and meet the requirement of society "a real man". A situation is created when several people depend economically on one breadwinner in the family. Circumstances force a man to choose a job with a higher pay. The responsibility of a large family income negatively affects parental responsibilities and leads to self-exclusion from raising children, a specific feature of Uzbek families.

Men who do not feel enough sense of self-sufficiency against the background of the public show "masculinity" by demonstrating firmness and toughness in emotional, mental and physical terms in the family. As a result, less manifestation of emotional feelings leads to depletion of relationships between men in a family with a wife and children. Social status leads to conflict and competition in the society of men themselves.

The mental toughness of men makes them look all-knowing. When faced with problems that exceed the mental abilities of a man, they begin to underestimate the assessment of others or isolate them in communication, which also negatively affects the self-development of men. With the manifestation of excessive physical strength, weak willpower and a low socio-economic status of a man are manifested. For his self- 
affirmation, a man mainly focuses on his family, as a result, women and children suffer.

Thus, the appropriate maintenance of the requirements of the male role leads men to gender-role stress and discomfort, and problems appear in communicating with people.

\section{CONCLUSION}

Socialization seems to impose on the human individual a certain system of knowledge, traditions, customs, norms that allow him to choose the function he will have to perform. Family, school, peers, parents, friends, environment, neighbors, acquaintances, relatives as the main institutions of socialization educate the individual in the direction in which it is beneficial to society. Once a person is born, he begins to assimilate the cultural and normative standards that are set by the public around him. For example, the process of gender socialization occurs mainly through the assimilation, perception and formation of male or female gender identity through mass information. People always expanding their horizons, changing their worldview, to a greater extent use not their own experience, but the information of the surrounding world. The growing person begins to adjust to the social and group norms inherent in his environment. Realizing himself, he can clearly say who he is "man" or "woman". And then comes the process of consolidating "male" or "female" norms. The public dexterously uses special cultural techniques in the form of education, public opinion, and works of literature, art, media, television and others to reinforce established trends in gender roles. If an individual shows attempts to protest, society severely rejects or punishes this process.

Social stratification has always been hierarchical, but the gender hierarchy has dominated over the years.

In history, the formation and development of women, in most cases, the demand for rights and freedom has always been severely punished. Basically, normative pressure on the individual occurs in a society devoid of democratic norms and recognition of gender equality.

\section{REFERENCES}

[1]. Gender Approach in Preschool Pedagogy: Monograph in Two Parts, under. ed. Candidate of Pedagogical Sciences L.V.Shtylevoy. - Murmansk. 2001Theory. p. 17.

[2]. Presidential Decree No. 2707 of February 29, 2016 "On measures to further improve the preschool education system in 2017-2021".

[3]. Statistical collection. "Men and women of Uzbekistan", publication of the Macroeconomic statistics of the Republic of Uzbekistan, Department of Statistics. Tashkent. 2002. - pp. 61-63.

[4]. Berstein B. (1975) Class, Codes and Control. - London.

[5]. Universal Declaration of Human Rights. Resolution 217 A. UN General Assembly of December 10, 1948.

2. Voronina O.A. Feminism and Gender Equality. M: Editorial URSS, 2004.

[6]. Universal Declaration of Human Rights (1948), article 2.

[7]. Civil Code of the Republic of Uzbekistan. - Tashkent. Ministry of Justice of the Republic of Uzbekistan. 2018.

[8]. Law "On Protection of Women from Oppression and Violence", 2019, Tashkent, https://www.lex.uz/docs/4494712.

[9]. Electoral Code of the Republic of Uzbekistan - Tashkent. Uzbekistan. 2019.

[10]. Kayumov. R. (1998) Constitutional law of the Republic of Uzbekistan. - Tashkent. Adolat. - p. 181.

[11]. Constitution of the Republic of Uzbekistan. - Tashkent Uzbekistan. 2018.

[12]. Radzhapova N.B. Participation of women in the economic life of Uzbekistan / N.B.Radzhapova. - Text: direct // Young scientist. - 2020. - No. 16 (306). - pp. 32-36. URL: https://moluch.ru/archive/306/68915/. 
[13]. Radjapova N. International experience in promoting gender equality, ISJ Theoretical \& Applied Science, Philadelphia, USA, may 30, 2020.

[14]. Orlova E. (1997). Simone de Beauvoir. Second version.

[15]. Action Strategy of Uzbekistan in 20172021 and the UN Sustainable Development Goals for the period up to 2030 2017. United Nations. - Tashkent. Uzbekistan.

[16]. Labor Code of the Republic of Uzbekistan. - Tashkent. Ministry of Justice of the Republic of Uzbekistan. 2011.

[17]. The Criminal Code of the Republic of Uzbekistan. - Tashkent. Ministry of Justice of the Republic of Uzbekistan. 2001.

[18]. Shtyleva L.V. (2001) Gender approach in preschool pedagogy: Monograph in two parts, under. Ed. Candidate of Pedagogical Sciences: L. V. Shtylevoy. - Murmansk. 